\title{
PEMURNIAN CATECHIN DARI GAMBIR KOTO PANJANG, PESISIR SELATAN
}

\author{
Norman Ferdinal \\ Laboratorium Kimia Organik Sintesis \\ Jurusan Kimia MIPA Universitas Andalas Padang, 25163
}

\begin{abstract}
The research about catechin purification from gambier was purposed to find its solubility properties in various solvent such as in cold water, hot water, hexane, ethyl acetate, and methanol. By knowing its solubility properties, the easiest way to purify the catechin could be gotten which is yielding about $7.33 \%$. Further, the molecular structure has been gotten by determining its melting point and using spectrophotometric measurements such as UV, IR, ${ }^{1} \mathrm{H}$ NMR, ${ }^{13} \mathrm{C}$ NMR. Based on those measurements, d-cathecin structure with a melting point of $175-177^{\circ} \mathrm{C}$ was founded. The expected benefit from this research is it could be benefiting the development of gambier purification industry in order to enhancing added value of West Sumatera's commodities. It would make Western Sumatera gaining stronger bargaining position due to the capability on selling not only on the crude form to abroad. The result of this research has indicated that catechin purification can be performed using an organic solvent and water.
\end{abstract}

Keywords: Purification, catechin, gambier

\section{DAFTAR PUSTAKA}

1. N. Nazir, Gambir: budidaya, pengolahan dan prospek diversifikasinya, Penerbit: Hutanku, 2000.

2. Aisman, N. Nazir, dan M. Djalal, Potensi produksi dan pertumbuhan nilai ekspor

4. http://www.alibaba.com/productfree/1210 166/Gambier extract.html, 04/03/2012

5. H. Mukhtar, Teknologi pemurnian gambir. makalah pada seminar nasional, Hasil-Hasil Penelitian dan Pengkajian Pertanian. BPTP Sukarami dan Peragi, 2000.

6.

N. Ferdinal dan N. Nazir, The Study of purifying of gambier by using the active carbon of the coconut shell of sawit, The $9^{\text {th }}$ International komoditi gambir, Prosiding Seminar Nasional TOI XXVI, 2004

3. Linkenheil dan Klaus. The Gambir processing industry in west sumatera. ATIAMI and Departemen Perindustrian dan Perdagangan Sumatera Barat, 1998.

Seminar on The Role of Chemestry in Industry and Enviroment, Jurusan Kimia FMIPA Unand. 2007

7. D. Darwis, Teknik isolasi, kromatografi dan kristalisasi dalam penelitian kimia bahan alam hayati, Workshop Peningkatan Sumberdaya Manusia Kajian Kimia Organik Bahan Alam Hayati dan Pelestarian Hutan, Jurusan Kimia FMIPA Universitas Andalas, 2002. 
